\title{
PETUNGAN SEBAGAI SISTEM UKURAN DALAM DESAIN KOMUNIKASI VISUAL JAWA
}

\author{
Irwan Harnoko \\ Universitas Bina Nusantara, Jakarta \\ irwanonni@yahoo.com
}

\begin{abstract}
Abstrak
Golden Ratio sering dipakai untuk mencari komposisi yang ideal baik dalam dunia arsitektur dan juga desain komunikasi visual. Sepintas seperti tidak ada masalah dengan menggunakan golden ratio sebagai tolak ukur pecarian proporsi dan komposisi ideal, namun bila mengukur proporsi dan komposisi ideal desain yang bersifat keNusantaraan dengan menggunakan golden ratio menjadi terasa aneh. Seakan Indonesia yang memiliki kekayaan budaya begitu banyak harus meng"import" ilmu dari luar untuk mengukur proporsi ideal karya Nusantara. Petungan ilmu ukur dari Primbon yang diciptakan oleh arsitek Prof. Dr. Ir. Josep Prijotomo menjadi salah satu jalan keluar dalam pencarian proporsi ideal yang bersifat keNusantaraan. Metode pencocokan yang diambil dari disertasi Prijotomo dipakai juga dalam proses pencocokan antara ilmu arsitektur, dkv dan gambar wayang Jawa. Hasil dari pencocokan tersebut memperlihatkan bahwa rumus arsitektur primbon dapat juga digunakan dalam proporsi wayang Jawa. Hasil temuan tersebut membuat penemuan prinsip baru dalam desain grafis Jawa. Dalam penulisan ini penulis melanjutkan hasil penemuannya dengan mengkoreksi ukuran kertas yang biasa dipakai secara standard internasional untuk kop surat A4 $(21 \times 29,7 \mathrm{~cm})$ dengan cara pola penghitungan sesuai petungan.
\end{abstract}

Katakunci: Petungan, Proporsi, Golden Section, Pencocokan

\begin{abstract}
Abstrak
Golden Ratio sering dipakai untuk mencari komposisi yang ideal baik dalam dunia arsitektur dan juga desain komunikasi visual. Sepintas seperti tidak ada masalah dengan menggunakan golden ratio sebagai tolak ukur pecarian proporsi dan komposisi ideal, namun bila mengukur proporsi dan komposisi ideal desain yang bersifat keNusantaraan dengan menggunakan golden ratio menjadi terasa aneh. Seakan Indonesia yang memiliki kekayaan budaya begitu banyak harus meng"import" ilmu dari luar untuk mengukur proporsi ideal karya Nusantara. Petungan ilmu ukur dari Primbon yang diciptakan oleh arsitek Prof. Dr. Ir. Josep Prijotomo menjadi salah satu jalan keluar dalam pencarian proporsi ideal yang bersifat keNusantaraan. Metode pencocokan yang diambil dari disertasi Prijotomo dipakai juga dalam proses pencocokan antara ilmu arsitektur, dkv dan gambar wayang Jawa. Hasil dari pencocokan tersebut memperlihatkan bahwa rumus arsitektur primbon dapat juga digunakan dalam proporsi wayang Jawa. Hasil temuan tersebut membuat penemuan prinsip baru dalam desain grafis Jawa. Dalam penulisan ini penulis melanjutkan hasil penemuannya dengan mengkoreksi ukuran kertas yang biasa dipakai secara standard internasional untuk kop surat A4 (21x29,7 cm) dengan cara pola penghitungan sesuai petungan.
\end{abstract}

Katakunci: Petungan, Proporsi, Golden Section, Pencocokan 


\section{PENDAHULUAN}

Penelitian ini bermula dari rasa penasaran penulis terhadap ilmu desain komunikasi visual (dkv) di Indonesia yang semua serba import. Dari pengamatan penulis di lapangan yang telah mengajar di perguruan tinggi di Indonesia khususnya di Jakarta pada jurusan dkv lebih dari enam belas tahun hingga kini, hampir tidak ada mata yang mengajarkan ilmu dkv yang bernafaskan keNusantaraan. Semua buku yang diajarkan hampir sebagaian besar import, seandaikata ada buku yang tidak import itupun sumbernya dari buku import. Hampir seluruh istilah yang diajarkan dalam jurusan dkv adalah berasal dari luar negeri terutama negara barat, misalnya: Gestalt, Semiotik, istilah-istilah dalam Tipografi (Leading, Kerning, Upper case, Lower case dll.), Golden Section dan masih banyak lagi. Muncul pertanyaan apakah Indonesia memang tidak punya keilmuan dkv yang bersifat lokal?

Hasil pembicaraan ringan dalam setiap perjumpaan dengan sesama dosen dkv di lingkungan kampus menggiring pada pembicaraan yang cukup serius untuk mencari keNusantaraan dkv. Pembicaraan yang bebas dan ringan tersebut menyimpulkan bahwa di Indonesia hampir semua ilmu yang berasal dari Indonesia dianggap bersifat tidak ilmiah dan klenik. Salah satu yang menjadi menarik dalam pembicaraan tersebut adalah mengungkit masalah primbon. Primbon adalah perhitungan-perhitungan ramalan, yang dalam bahasa Jawa dikenal dengan istilah petungan. (Wijoyo, 2009:x)

Berangkat dari ide awal tersebut, yaitu Primbon. Penulis mencoba mencari di Internet, apakah sudah ada penulis lain yang mengulas primbon dalam sudut pandang dkv dalam bentuk Jurnal ataupun yang lainnya? Ternyata pencarian tersebut gagal. Pencarian penulis di- lanjutkan dengan mencoba menghubungkan antara dkv (yang pada tahun 1990an di Indonesia masih disebut dengan istilah desain grafis) dengan disiplin ilmu lainnya. Ilmu Arsitektur adalah salah satu target pencarian tersebut. Mengapa arsitektur menjadi bagian pencarian penulis dalam proses pencarian? Hal ini dikarenakan beberapa desainer grafis terkenal mancanegara mempunyai pengetahuan arsitektur dan memakainya sebagai sumber inspirasi dalam mereka membuat desain. Wim Crouwel dari Belanda, Massimo Vignelli dari Amerika, Josef Müller-Brockmann dari Swiss mempergunakan arsitektur dalam banyak bergaul dengan para aristek. Nama Prof. Dr. Ir. Josep Prijotomo ditemukan dalam pencarian di internet dalam buku "Petungan - sistem ukuran dalam Arsitektur Jawa". Prijotomo mengatakan seharusnya para pecinta arsitektur akan tertantang dengan kenyataan bahwa arsitektur tradisional Cina telah berhasil diturunkan disertasi tentang Feng-shui atau Geomancy. (Prijotomo, 1995: 2).

Dunia desain grafis dan arsitek adalah dua keilmuan yang berbeda, namun pada hakekatnya memiliki persamaan dalam upaya mencapai fungsi dan nilai estetika; salah satunya adalah Golden Section. The Golden Section (disebut pula dengan 'proporsi agung' atau 'rasio emas'), ditemukan oleh Leonardo Fibonacci dari italia pada abad 12 , pada penerapannya dapat dipakai dalam ilmu arsitek maupun desain grafis. Sedangkan di Indonesia kita telah mengenal Primbon yang menyediakan sederetan patokan me-ngenai perbandingan ukuran, yang oleh masyarakat Jawa banyak dikenal dengan sebutan Petungan. Khusus dalam ihwal Primbon, nampaknya sudah terlanjur tertanam anggapan bahwa naskah yang satu ini adalah tak-ilmiah, klenik, dan berbagai sebutan negatif lainnya. (Prijotomo, 1995:2) 
Desain grafis adalah seni dalam berkomunikasi menggunakan tulisan, ruang, dan gambar. Bidang ini merupakan bagian dari komunikasi visual. Ilmu desain grafis mencakup seni visual, tipografi, tata letak, dan desain interaksi. Arsitektur adalah seni dan ilmu dalam merancang bangunan. Dalam artian yang lebih luas, arsitektur mencakup merancang dan membangun keseluruhan lingkungan binaan, mulai dari level makro yaitu perencanaan kota, perencanaan perkotaan, arsitektur lansekap, hingga ke level mikro yaitu desain bangunan, desain parabot dan desain produk. Arsitektur juga merujuk kepada hasil-hasil proses perancangan tersebut. Letak persamaan ilmu ini desain grafis dan arsitektur adalah keduanya mementingkan proporsi keindahan yang dalam hal ini alat yang digunakan sebagai panduan universal adalah Golden Section.

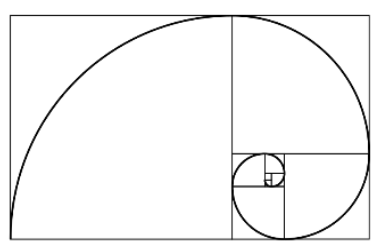

Gambar 1. Pembagian Golden Section pada Segmentasi Keong Sumber: http://mathworld.wolfram.com

Golden Section atau rasio emas adalah istilah yang banyak digunakan di bidang matematika. Sesuatu disebut sebagai rasio emas bila rasio (perbandingan) dari jumlah dua bagian (besar + kecil) terhadap bagian yang besar bernilai 1,61803398874989. Dari Golden Section, dapat terbentuk golden rectangles, yang bila disusun terus menerus seperti pada ilustrasi berikut akan menghasilkan pola bentuk spiral, seperti pola spiral pada segmentasi keong. Golden Section ini banyak diaplikasikan sebagai suatu kaidah perancangan pada arsitektur klasik.
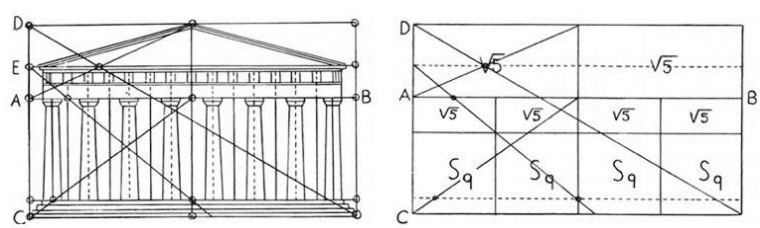

Gambar 2. Pembagian Golden Section pada bangunan Parthenon Sumber: http://mathworld.wolfram.com

Contohnya pada bangunan Parthenon berikut, yang menggunakan kaidah golden rectangles (atau golden proportions) mulai dari lingkup bangunan secara keseluruhan sampai pada detail terkecilnya. Tidak hanya digunakan pada arsitektur, kaidah tersebut juga banyak diaplikasikan pada karya seni klasik, seperti patung atau lukisan.

Arsitektur Jawa juga mengenal dan menggunakan proporsi. Memang hal ini tidak memiliki Golden Section atau Pembagian emasnya Leonardo da Vinci yang sangat terkenal di kalangan teknisi dan seniman di mana-mana. Namun masyarakat Jawa memiliki norma tersendiri dalam menentukan proporsi. Mereka menggunakan perhitungan: Sri, Kitri, Gana, Liyu, dan Pokah. Hal terebut diutarakan oleh Zein Moedjijono WP (1985) dalam tulisan yang berjudul 'Arsitektur Jawa (ayu-ayom-ayem)'. Dalam penelitian ini penulis akan memakai kajian dari Josef Prijotomo yang mempunyai perbedaan dari Moedjijono adalah dalam bentuk rumus yang $(5 n+p)$, di mana $n$ adalah bilangan bulat yang oleh Moedjijono diberi tanda $\mathrm{X}$, sedangkan $\mathrm{p}$ adalah sisa hitungan dari pengurangan lima-lima (yang dalam Moedjijono diberi tanda bilangan 1) (Prijotomo, 1995: 17)

Geometri merupakan suatu dasar pemikiran akan bentuk, mulai dari bentuk yang ada pada alam hingga bentuk yang merupakan suatu arsitektur. Namun apakah setiap bentuk dalam arsitektur pasti terdiri dari elemen geometri? Untuk dapat menjawab pertanyaan ini, maka 
sebaiknya dikenal lebih dahulu apa itu yang disebut dengan geometri. Menurut World Book Encyclopedia, geometri didefinisikan sebagai berikut:

"Geometry is a branch of mathematics. It involves studying the shape, size, and position of geometric figures. These figures include plane (flat) figures, such as triangles and rectangles, and solid (threedimensional) figures, such as cubes and spheres" (The World Book Encyclopedia, 1993)

Dalam definisi tersebut, dijelaskan bahwa geometri merupakan suatu ilmu matematika yang sangat terkait dengan bentuk, ukuran, dan pemposisian. Definisi ini sangat luas, sehingga dengan hanya berpedoman pada definisi ini, maka tiap bentuk dapat dikategorikan sebagai suatu geometri dan juga terdiri dari elemen geometri.

Dari keilmuan desain grafis, kita mengenal desainer Josef MullerBrockmann dari Swiss yang karya desain grafisnya sangat arsitektural, dimana dia menjelaskan bahwa dalam geometri: "The proportions of the formal elements and their intermediate spaces are almost always related to certain numerical progressions logically followed out" (Elam, 2001: 5).

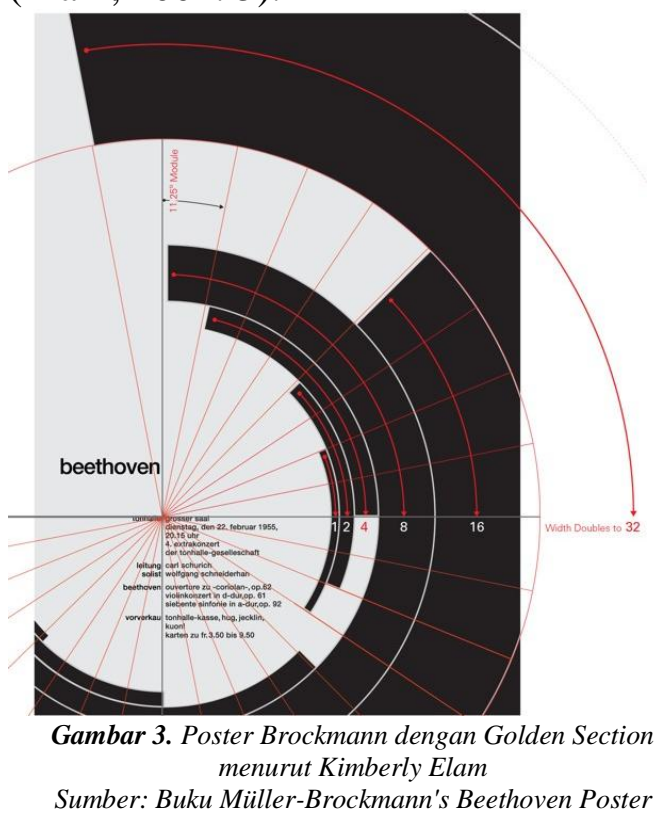

Menurut penjelasan tambahan dari Muller-Brockmann, proporsi dari elemen formal dan ruang dalam geometri selalu terkait dengan perhitungan numerik yang logis. Sebagai salah satu ilmu matematika, geometri tentunya memiliki aturan-aturan yang membatasi bentuk yang dimilikinya.

Dengan sifat bentuk geometri yang terkait dengan elemen numerik dan harus memiliki suatu bentuk yang logis, maka variasi bentuk pada geometri pun menjadi berkurang. Objek-objek yang bersifat abstrak, cenderung memiliki bentuk yang tidak logis dan tidak dapat didefinisikan sebagai bentuk numerik. Hal ini dikarenakan elemenelemen pembentuknya tidak terukur. Oleh karena itu objek-objek ini tidak dapat dikategorikan sebagai bentuk geometri.

Berdasarkan penjelasan tersebut di atas maka peneliti akan membuat metode proporsi ideal desain grafis Indonesia khususnya dalam konteks Jawa Tengah melalui Petungan yang hal tersebut dilakukan terinspirasi oleh Josef Muller-Brockmann. Sebab kedua hal ini memiliki aplikasi proporsi pada dunia keilmuan desain grafis, maka peneliti yakin dapat pula melakukan proses aplikasi proporsi yang juga pada keilmuan desain grafis, namun dengan proporsi dari petungan.

Adapun tujuan jangka panjang penelitian ini adalah menempatkan Petungan sebagai salah satu alat ukur selain Golden Section untuk membuat sistem proporsi yang dapat digunakan dalam menyusun keseimbangan sebuah desain grafis. Target khusus penelitian ini adalah mengoptimalkan penggunaan Petungan sehingga menghasilkan proporsi layout ideal untuk desain grafis Indonesia khususnya Jawa Tengah, serta mensosialisasikannya kepada rekan sesama desainer, industri dan masyarakat umum, sehingga keutamaan penelitian ini 
adalah memberikan inspirasi untuk mengembangkan Local Genius Indonesia yang lain terutama dalam proporsi keindahan dari beragam budaya di Indonesia dalam rangka persaingan AFTA 2015.

\section{METODE PENELITIAN}

Metode yang dilakukan adalah melalui proses metode pencocokan pada penelitian ini, peneliti melakukan perbandingan proporsi petungan dengan obyek nyata pada aplikasi desain grafis beserta turunannnya, yang dijalankan dengan cara memasukkannya dalam fase fenomenologi. Sehingga hasil perancangan desain grafis dapat ditemukan adanya kesamaan, kemiripan, keserupaan, atau selisih, dan kebedaaan dari rumusan proporsi baru petungan ini. (Prijotomo, 2006: 33). Hal ini telah dikonfirmasikan pada Prof. Dr. Ir. Josep Prijotomo saat penulis mendatangi kediamannya di komplek perumahan Institut Teknologi Surabaya pada tanggal 8 0ktober 2016 jam 11.00 W.I.B.

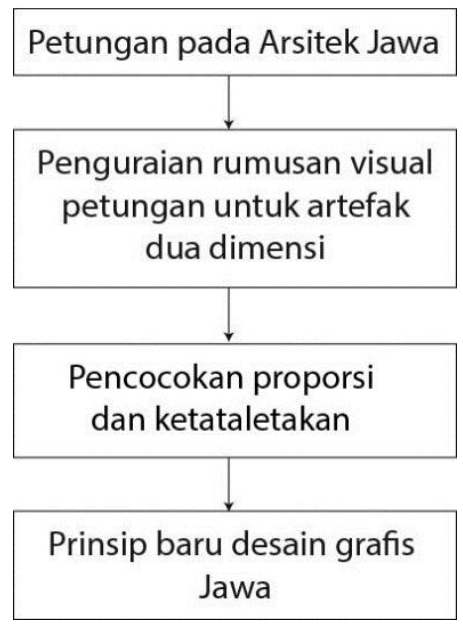

Gambar 4. Metode Penelitian Rumusan Proporsi Petung Sumber: Karya Penulis

\section{HASIL DAN PEMBAHASAN}

Berdasarkan metode pencocokan (matching) yang didapat oleh penulis dari buku disertasi (Re-) Konstruksi Arsitektur Jawa yang ditulis oleh Prof. Dr. Ir. Josep Prijotomo serta hasil wawancara dengan beliau maka penulis mencoba mengurai rumus Prijotomo dengan dialihkan $5 n+P$ ke media dua dimensi.

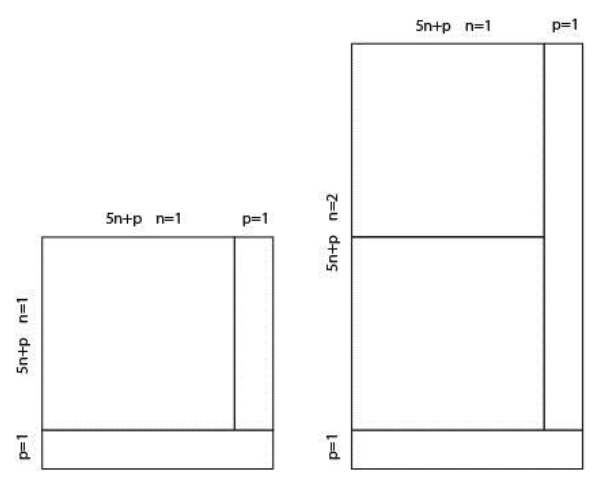

Gambar 5. Metode Pencocokan, pengalihan rumus Prijotomo ke media 2 dimensi Sumber: Karya Penulis

Pada Gambar 5 dijelaskan bahwa rumus Prijotomo $5 n+p$ dapat diilustrasikan seperti itu. Variabel n pada panjang dan lebar dapat berbeda. Pada kesempatan kali ini penulis mencoba untuk mempertahankan variabel $\mathrm{p}$ pada sisi vertikal tetap pada nilai 1 .

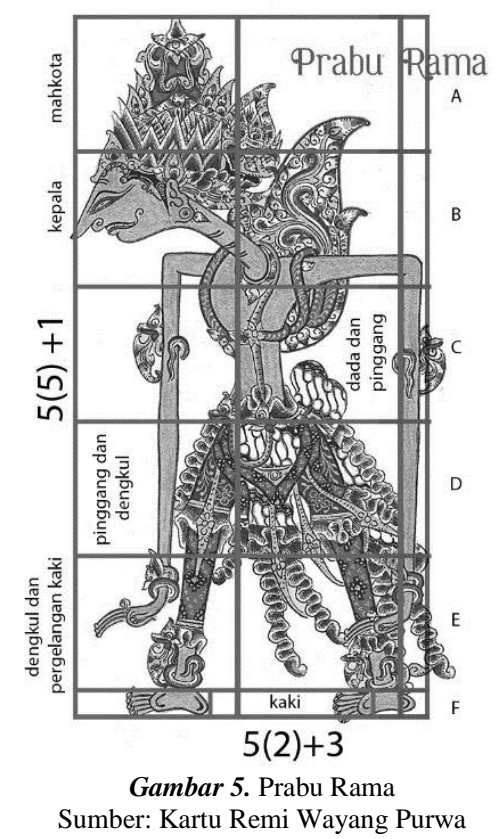


Penulis adalah pemilik dari kartu remi wayang purwa. Kartu remi wayang purwa adalah berisi tokoh-tokoh wayang dari tokoh Mahabaratha dan Ramayana. Pada Gambar 5 ini dibuat oleh bapak Sugiri dari museum wayang Jakarta hasil pesanan dari penulis kurang lebih 10 tahun yang silam. Penulis memesan 56 tokoh wayang purwa pada beliau. Dapat dikatakan bahwa pembuatan gambar wayang ini tidak ada hubungannya dengan pencarian proporsi ideal yang sedang diteliti penulis pada tahun 2016 ini. Dapat dilihat ketika rumus Prijotomo diletakan pada gambar pak Sugiri hasilnya menunjukan ketepatan proporsi. Pada bagian A dapat terlihat bahwa kotak ditempatkan pada wilayah mahkota. Pada bagian B kotak berada di wilayah kepala dan leher, pada bagian $\mathrm{C}$ kotak berada di wilayah dada dan pinggang, pada bagian D kotak berada di wilayah pinggang dan dengkul, pada bagian E kotak berada di wilayah dengkul dan pergelangan kaki. Pada bagian $\mathrm{F}$ adalah wilayah kaki.

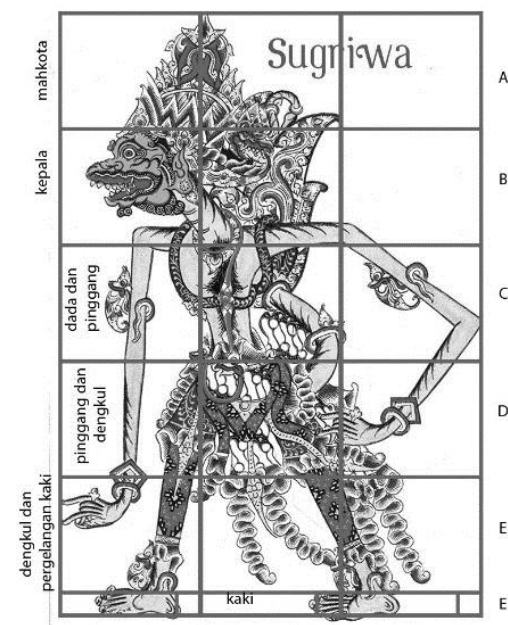

Gambar 5. Sugriwa Sumber: Kartu Remi Wayang Purwa

Pada Gambar 6 dapat dilihat bahwa proporsi Sugriwa dan Prabu Rama mempunyai persamaan proporsi.

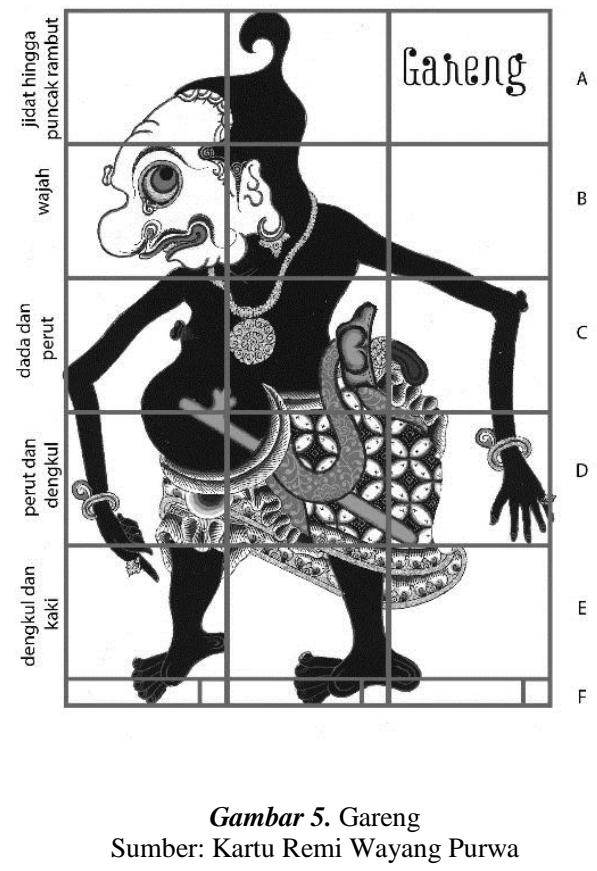

Terdapat perbedaan peruntukan khusus bagi panakawan. Penulis di sini tidak dapat menunjukkan seluruh panakawan dan wayang purwa lainnya baik dari sisi pandawa maupun kurawa dikarenakan aturan penulisan jurnal, namun pada prinsipnya dapat terlihat bahwa rumus Prijotomo ini sangat akurat untuk proporsi wayang Indonesia. Tidak hanya itu, penulis sudah mencoba dalam wayang bali Klungkung - Kamasan dan juga pada keris.

Pada ukuran kertas A4 (21 x 29,7 $\mathrm{cm})$, ketika menggunakan proporsi petungan, itu akan berubah; di mana penulis menggunakan patokan ' $n$ ' sebagai pembulatan $20 \mathrm{~cm}$ untuk lebar dan $30 \mathrm{~cm}$ untuk tinggi (dasar kelipatan 10). Nilai 'p' menjadi lebihan oleh 1 , sehingga penerapan petungan untuk kertas ukuran A4 ke $20+1 \mathrm{~cm}$ untuk lebar dan $30+1$ $\mathrm{cm}$ untuk tinggi, atau total pengukuran 21 $\mathrm{x} 31 \mathrm{~cm}$.

Metode ini juga dapat diterapkan untuk golden section dari ukuran kartu nama. Ukuran umum dari kartu nama adalah $5.5 \times 9 \mathrm{~cm}$ bila diterapkan dalam proporsi petungan juga akan berubah; di mana penulis menggunakan patokan ' $n$ ' 
sebagai bilangan bulat dari $5 \mathrm{~cm}$ untuk lebar dan $5 \mathrm{~cm}$ untuk tinggi (base kelipatan 5). Nilai ' $p$ ' menjadi lebihan oleh 1, sehingga penerapan petungan untuk kertas ukuran A4 menjadi $5+1 \mathrm{~cm}$ untuk lebar dan $5+1+1+1 \mathrm{~cm}$ untuk tinggi, atau pengukuran total $6 \times 8 \mathrm{~cm}$.

\section{SIMPULAN}

Dari hasil penemuan yang telah dipaparkan di atas dapat dikatakan bahwa ilmu yang bersifat keNusantaraan sangat layak untuk dikembangkan. Seperti yang telah dikatakan oleh Prijotomo bahwa arsitektur Indonesia berbeda dengan arsitektur di Indonesia, hal ini berlaku juga dengan dkv. Dkv Indonesia berbeda dengan dkv di Indonesia. Melalui tulisan ini setidaknya hal ini merupakan langkah awal menuju dkv yang autoktonos (Frick, 1997:9) dan mengurangi kebohongan fatal dari sekolah $\mathrm{dkv}$ adalah kalau keNusantaraan dikesampingkan dengan alasan tidak/belum lengkap ilmunya, belum/tidak tersedia bahan ajarnya. Adalah tugas sekolah dkv untuk mengadakan ilmu dan bahan ajar, bukan menghindar. Ini adalah pembohongan dalam usaha mengingkari janji dan tanggung jawab. (Prijotomo 2004:27).

\section{Penghargaan}

Penghargaan kepada Prof. Dr. Ir. Josep Prijotomo yang telah memberikan waktunya di kediamannya di komplek perumahan Institut Teknologi Surabaya pada tanggal 8 0ktober 2016 jam 11.00 W.I.B. dalam penyelesaian penulisan naskah.

\section{DAFTAR PUSTAKA}

Igawa, N. and H. Nakamura, (2001). All Sky Model as a standard sky for the simulation of daylit environment. Building and Environment, 36: p. 763-770.

International Daylight Monitoring Programme, [Online], Available: http://idmp.entpe.fr/ [16 June 2008].

Kittler, R., (1985). Luminance distribution characteristics of homogeneous skies: a measurement and prediction strategy. Lighting Research and Technology, 17(4): p. 183-8.

Perraudeau, M., (1988). Luminance models. In National Lighting Conference. Cambridge, UK, March 27-30.

Elam, K. (2004). Müller-Brockmann's Beethoven Poster - Geometrc Analysis. Princeton Architecture Press. New York. 